\title{
Effects of Feeding Different Levels of Baker's Yeast on Performance and Hematological Parameters in Broiler Chickens
}

\author{
Kassech Mulatu ${ }^{1}$, Negassi Ameha ${ }^{2}$ and Meseret Girma ${ }^{3 *}$ \\ School of Animal and Range Sciences, Haramaya University, PO Box 138, Dire Dawa, Ethiopia \\ *Corresponding author`s Email: meseretgirma4@ gmail.com; ORCID: 0000-0001-8724-9447
}

Received: 21 Apr. 2019

Accepted: 18 May. 2019

\begin{abstract}
The effects of feeding baker's yeast performance of Cobb 500 broilers were studied. Four nearly isocaloric and isonitrogenous starter and finisher rations were prepared. 240 chicks with an average initial body weight of $42 \mathrm{~g}$ were randomly divided into 12 groups contained 4 treatments with 3 replications for each treatment. Treatment rations were containing $0,0.5,1.5$ and $2.5 \%$ of baker's yeast as T1, T2, T3 and T4 respectively. At the end of the trial, 3 males and 3 female chickens from each replication were slaughtered for carcass evaluation. The Crude Protein (CP) and Metabolizable Energy (ME) contents of baker's yeast were $48 \%$ and $3615 \mathrm{kcal} / \mathrm{kg}$ DM, respectively. The CP content of the rations during the starter and finisher phases were $22 \%$ and $20 \%$, respectively. The ME content of the rations during the starter and finisher phases were $3100 \mathrm{kcal} / \mathrm{kg}$ and $3200 \mathrm{kcal} / \mathrm{kg}$ respectively. Feed intake during the starter phase and entire trial period was lower for T4, whereas during the finisher phase in control diet group showed the highest feed intake than the other supplemental groups. The highest daily body weight gain was recorded in broilers fed T4 rations during starter phase, finisher phase and entire experimental period. Feed conversion ratio of T4 and T3 groups was better than T2 and T1. T3 and T4 groups had higher eviscerated percentages. Blood parameters results showed that fed broilers yeast containing ration had higher WBC, PCV and $\mathrm{Hb}$. Partial budget analysis indicated that the highest net income, marginal rate of return and chicks' sale to feed cost were obtained for T3 followed by T4. Baker's yeast can be an important feed additive, which can be included up to $2.5 \%$ of the total ration and improve the overall performance of broilers without compromising the hematological indices of broiler chickens. Key words: Baker's yeast, Blood constituents, Broiler, Carcass and Growth
\end{abstract}

\section{INTRODUCTION}

Broiler production represents nearly $33 \%$ of global meat production and is a source of protein that plays an important role in human nutrition (FAO, 2010). Modern intensive poultry production produces market ready broiler chickens within six weeks of their age. This achievement arises from improved productivity via genetic selection, improved feeding and health management practices involving usage of antibiotics as therapeutic agents to treat bacterial diseases and as feed additives for growth promotion (Apata, 2009). One of the major challenges faced by the poultry industry in the developing world is improving efficiency of production. To meet this challenge and maintain the efficiency of feed utilization, series of attempts have been made by different researchers and organizations. These include incorporation of genetics selection, antimicrobials and other natural products, such as antibiotics as therapeutic agents to treat bacterial diseases and as feed additives for growth promotion, probiotics, vitamin supplements and antibodies to animal feeds and pelleting of feed, all decrease the time that an animal requires to reach market weight, reducing feed and overall cost (Kanwal et al., 2017). Two main groups of feed additives are the nutrient feed additives and nonnutrient feed additives. The nutrient feed additives are added in the feed to correct quantity of the deficient nutrients in the rations, such as vitamin mix, mineral mix and single or the mixture of amino acids. While the nonnutrient feed additives such as color and taste enhancers, appetizers, enzymes, yeast, growth promoters and probiotics are added in the feed to improve or to accelerate the rate of feed or nutrient utilization (Kemal et al., 2001).

Addition of Live yeast to animal feed has been known for improving the animals health symptoms 
(Kanwal et al., 2017). For a long time, yeast products have been successfully included in feed as natural growth promoters for livestock and poultry production. Many types of yeast have been fed to animals either in the form of yeast fermented mash produced on farm, yeast byproducts from breweries or distilleries and commercial yeast products (Kemal et al., 2001; Saied et al., 2011). Currently, in many parts of the world, food additives, such as probiotics and prebiotics are being experimented to alleviate the problems associated with the withdrawal of antibiotics from feed. Probiotic is defined as a live microbial feed supplement which beneficially affects the host animal by improving its intestinal microbial balance (Fuller, 2000). It is a biological product, which stimulates the immunity system (Toms and Powrie, 2001), produces the digestive enzyme and increases its defensive activity against pathogenic bacteria and stops the implementation of those bacteria over the mucosa of the intestine (Rolfe, 2000).

Baker's yeast (Saccharomyces cerevisiae) is considered as one of the live microorganism probiotic that is used as feed additive. It can improve body weight gaining, feed efficiency, stimulate the immunity system and increase its defensive activity against pathogenic bacteria and also reduces feed cost by shortening the length of feeding (Fietto et al., 2004; Graff et al., 2008; Patane et al., 2017; Mohamed et al., 2015). Even though in Ethiopia incorporating yeast in ration specially baker's yeast is not widely used, it is one of the most widely available in Ethiopia. Therefore, the current experiment was conducted with the following objectives:

To evaluate the effects of feeding different levels of baker's yeast ( $S$. cerevisiae) on feed intake, growth performance and carcass characteristics of broiler chicks; To assess the effects of baker's yeast on hematological indices of broiler chicks and to determine the economic profitability of using baker's yeast in the ration of broilers.

\section{MATERIALS AND METHODS}

\section{Experimental site}

The experiment was conducted at Haramaya University poultry farm, Ethiopia, which is located at an altitude of 1980 meters above sea level and $515 \mathrm{~km}$ east of Addis Ababa. The area is located at latitude and longitude of $9^{0} 26^{\prime} \mathrm{N}$ and $42^{0} 3^{\prime} \mathrm{E}$, respectively. The average annual rainfall of the area is $780 \mathrm{~mm}$ with an average minimum and maximum temperatures are $8^{\circ} \mathrm{C}$ and $24^{\circ} \mathrm{C}$, respectively (Samuel, 2008).

\section{Experimental feeds}

Feed ingredients of the study were formulated using the common broiler feeds. The ingredients used for ration formulation were soybean meal, noug seed cake, corn grain, wheat short, vitamin premix, di-calcium phosphate, limestone, baker's yeast, salt, lysine and methionine. The food ingredients that are corn grain and noug seed cake were hammer milled at $5 \mathrm{~mm}$ sieve size and mixed based on dry matter basis. Lysine, methionine, di-calcium phosphate and vitamin premix were added to the feed during mixing without hammer milling. Representative samples of food ingredients soybean meal, noug seedcake, corn grain and wheat short as well as additive which are baker's yeast were analyzed for chemical composition before ration formulation.

For the period of both starter and finisher phases, treatment rations containing baker's yeast at levels of $0 \%$, $0.5 \%, 1.5 \%$, and $2.5 \%$ of the total ration were formulated for $\mathrm{T} 1, \mathrm{~T} 2, \mathrm{~T} 3$ and $\mathrm{T} 4$, respectively by using feed win software. The four treatment rations used in the study were formulated to contain approximately $22 \%$ and $20 \%$ CP and 3100 and $3200 \mathrm{kcal} / \mathrm{kg}$ ME for starter's and finisher's diet respectively. The starter phase was until the age of 3 weeks. The finisher phase was offered from fourth up to sixth weeks. The starter and finisher diets were formulated separately as indicated in tables 1 and 2 .

\section{Experimental design and treatments}

Completely Randomized Design (CRD) with four treatments and three replicates was used in the study. Twelve pens were used for the two hundred and forty day old chicks and 20 chicks were randomly assigned to each pen (Table 3).

Table 1. Percentage of ingredients used in formulating starter ration of broiler chicken

\begin{tabular}{lcccc}
\hline Ingredients (\%) & T1 & T2 & T3 & T4 \\
\hline Corn grain & 44.0 & 44.0 & 44.0 & 44.0 \\
Wheat short & 11.0 & 11.0 & 10.5 & 10.0 \\
SBM & 25.0 & 25.0 & 25.0 & 25.0 \\
NSC & 17.5 & 17 & 16.5 & 16.0 \\
BY & 0.0 & 0.5 & 1.5 & 2.5 \\
Lime stone & 1 & 1 & 1 & 1 \\
Common salt & 0.5 & 0.5 & 0.5 & 0.5 \\
VP & 0.4 & 0.4 & 0.4 & 0.4 \\
DCP & 0.3 & 0.3 & 0.3 & 0.3 \\
Lysine & 0.1 & 0.1 & 0.1 & 0.1 \\
Methionine & 0.2 & 0.2 & 0.2 & 0.2 \\
Total & 100.00 & 100.00 & 100.00 & 100.00 \\
ME $($ kcal $)$ & 3038.23 & 3043.71 & 3054.7 & 3062.37 \\
CP $(\%)$ & 21.7 & 21.82 & 21.98 & 22.06 \\
\hline SBM= soybean meal; NSC $=$ noug seed cake; BY= baker's yeast; VP= \\
vitamin premix; DCP= di-calcium phosphate; ME= metabolizable \\
energy; CP= crude protein.
\end{tabular}


Table 2. Percentage of ingredients used in formulating finisher ration of broiler chicken

\begin{tabular}{lcccc}
\hline Ingredients (\%) & T1 & T2 & T3 & T4 \\
\hline Corn grain & 55.0 & 55.0 & 55.0 & 55.0 \\
Wheat short & 8.0 & 7.5 & 7.5 & 7.0 \\
SBM & 22.0 & 22.0 & 22.0 & 22.0 \\
NSC & 12.5 & 12.5 & 11.5 & 11.0 \\
BY & 0.0 & 0.5 & 1.5 & 2.5 \\
Limestone & 1 & 1 & 1 & 1 \\
Salt & 0.5 & 0.5 & 0.5 & 0.5 \\
VP & 0.4 & 0.4 & 0.4 & 0.4 \\
DCP & 0.3 & 0.3 & 0.3 & 0.3 \\
Lysine & 0.1 & 0.1 & 0.1 & 0.1 \\
Methionine & 0.2 & 0.2 & 0.2 & 0.2 \\
Total & 100 & 100 & 100 & 100 \\
ME(kcal) & 3100.51 & 3104.34 & 3112.01 & 3123 \\
CP \% & 19.47 & 19.93 & 20.00 & 20.03 \\
\hline SBM soybean & NSC $=$ noug &
\end{tabular}

$\mathrm{SBM}=$ soybean meal; $\mathrm{NSC}=$ noug seed cake; $\mathrm{BY}=$ baker's yeast; $\mathrm{VP}=$ vitamin premix; $\mathrm{DCP}=$ di-calcium phosphate; $\mathrm{ME}=$ metabolizable energy; $\mathrm{CP}=$ crude protein.

Table 3. Experimental design

\begin{tabular}{ccccc|ccc}
\hline \multirow{2}{*}{ Treatment } & \multirow{2}{*}{$\begin{array}{c}\text { No of } \\
\text { Replication }\end{array}$} & \multicolumn{3}{c|}{$\begin{array}{c}\text { Starter Phase } \\
\text { Replicks/ }\end{array}$} & \multicolumn{3}{c}{ Finisher Phase } \\
\cline { 3 - 8 } & & \multicolumn{2}{c}{$\begin{array}{c}\text { Chicks/ } \\
\text { Replication }\end{array}$} \\
\cline { 3 - 8 } & R1 & R2 & R3 & R1 & R2 & R3 \\
\hline T1 & 3 & 20 & 20 & 20 & 18 & 19 & 17 \\
T2 & 3 & 20 & 20 & 20 & 18 & 19 & 19 \\
T3 & 3 & 20 & 20 & 20 & 20 & 18 & 20 \\
T4 & 3 & 20 & 20 & 20 & 19 & 19 & 18 \\
\hline
\end{tabular}

\section{Management of experimental chicks}

The experimental house was cleaned and disinfected 3 weeks before the chicks' arrive. The pens were washed and sprayed with commercial disinfectant labeled for use in the poultry farm. The feeding and drinking troughs were properly cleaned, dried and disinfected before chicks' arrival. 240 day old chicks with $42 \mathrm{~g}$ average weigh (Cobb 500, commercial broiler strains) were purchased from Debre Zeit Elere Farm, Ethiopia. For these chicks, 12 pens were used and their floors were covered with disinfected wood shaving. Each pen was also equipped with a 250watt infrared heat bulb. Feeding was twice a day at 08:00 and 16:00 hours ad libitum. Watering was also given $a d$ libitum by washing the watering troughs properly. The chicks were vaccinated against common diseases in the area. Other health precautions and disease control measures were taken throughout the study period.

Chemical analysis of food ingredients. The chemical analyses of experimental feeds were done at Haramaya University Nutrition Laboratory by taking representative samples. Samples were taken from each food ingredients. Each ingredient was analyzed for their nutrients composition of DM, CP, EE, CF and total ash using the Weende or Proximate analysis method of the AOAC (1995). Metabolizable energy (ME) content of the feed ingredients as well as experimental diets was determined by using indirect method of Wiseman (1987) as follows: $\mathrm{ME}(\mathrm{kcal} / \mathrm{kg} \mathrm{DM})=3951+54.4 \mathrm{EE}-88.7 \mathrm{CF}$ - 40.80 Ash

Feed intake. Daily feed consumption was determined as the difference between the feed offered and refused. Feed offered and refusals were weighed and recorded every day in the morning. Mean daily Feed intake per bird was computed as;

$$
\text { Mean daily feed intake }=\frac{\text { Mean total feed intake }}{\text { No of experimental days }}
$$

Body weight gain. Body weight gain was assessed every week by weighing the chicks with sensitive balance. The body weight gain of birds was computed by subtracting mean initial weight from the mean final weight. Daily body weight gain (ADG) was determined as a difference between mean final and mean initial body weights divide by the number of experimental days.

Feed conversion ratio. The mean feed conversion ratio was determined by dividing the average daily feed intake (DFI) with a mean daily body weight gain (DBWG).

Carcass measurements. At the end of the experiment, six broilers were randomly picked from each replication for carcass evaluation. The birds were slaughtered after being starved for about 12 hours and weighed. After slaughtering, bleeding and de-feathering dressing percentage (DP\%) was calculated as

$$
\mathrm{DP} \%=\frac{\text { Carcass weight }}{\text { Live weight }} \times \mathbf{1 0 0}
$$

Eviscerated percentage was calculated by removing the viscera, head, shank, trachea and lungs but with giblets (heart, liver, and gizzard) and skin and expressed as percent of live weight. Abdominal fat was determined by weighing the fat trimmed from proventriculus up to cloacae. Its percentage was calculated as the proportion of slaughter weight and multiplied by hundred. Breast meat weight was measured individually and equated with percent live weight. Drumstick and thigh together were measured and expressed as percent of the live weight. The edible offal (heart, liver and gizzard), kidney and spleen were weighed after separated from the visceral and their percentages were determined in relation to slaughter weight. The length and weight of small intestine, ceaca, proventriculus and crop were measured using a centimeter tape and sensitive balance. 
Hematological parameter analysis. At the end of experiment period, six broilers were randomly selected from each replicate of each treatment groups and blood samples were taken from the bronchial vein with a syringe on a tube containing anticoagulant (heparin solution) for analysis of hematology parameters (Hemoglobin, Packed Cell Volume, Total white blood cell and red blood cell). Hemoglobin $(\mathrm{Hb})$ was determined from samples before spinning in centrifuge by the method of Acid hematin. Packed cell volume (PCV) was determined by spinning blood filled capillary tubes in a centrifuge at 1200 revolutions per minute (rpm) for 5 minutes and reading on hematocrit reader. Total white blood cell (WBC) and red blood cell (RBC) counts were determined by using hemocytometer. The hematological parameters were determined as described by Dacie and Lewis (1991). At the time of slaughter, gastrointestinal tract and organs were examined for any pathological symptoms and gross lesions were recorded when observed.

Mortality. Mortality was recorded as it occurred and was determined for each treatment as a percentage of the total mortality at the end of the whole experiment.

\section{Partial budget analysis}

The net profits from broiler were calculated based on the cost of feed that each bird consumed from the respective treatments and the other costs. To estimate net benefit of baker yeast feeding, the partial budget was analyzed by consideration of the whole feed expense according to the principles developed by put (Upton, 1979). The partial budget analysis involves calculation of the variable cost and benefits. Partial budget measures the chicken cost, feed and others if any and the profit after the experiment, or differences between gains and losses for the proposed change.

Total variable cost includes the cost of feeds and other costs. The selling prices of broilers were determined by using the average current market price of broiler carcass per kilogram. Total return (TR) was considered as the difference between sale and purchase price in the partial budget analysis. The net income (NI) was expressed by subtracting total variable cost (TVC) from total return (TR). NI $=\mathrm{TR}-\mathrm{TVC}$ The change in net income $(\Delta \mathrm{NI})$ was expressed as the difference between the changes in total return $(\Delta T R)$ and total variable cost $(\triangle \mathrm{TVC})$. The marginal rate of return (MRR) measures the increase in net income $(\Delta \mathrm{NI})$ related with each additional unit of expenditure $(\triangle \mathrm{TVC})$ as follows;

$$
\mathrm{MRR}=\frac{\Delta \mathrm{NI}}{\Delta \mathrm{TVC}}
$$

The sale of chicks to cost of feed ratio was calculated as additional parameter to evaluate profitability and use efficiency of the rations as;

$$
\frac{\text { Sales of chick's (Birr) }}{\text { Cost of feed (Birr) }}
$$

\section{Ethical approval}

This research was carried out as a part of Master of Science in Agriculture (Animal production) research after the approval of competent authority of the director of research and post graduate study, Haramaya University, Ethiopia.

\section{Statistical analysis}

Data of the experiment was subjected to ANOVA using the General Linear Model (GLM) procedure (SAS, 2008). When the analysis of variance revealed significant differences, treatment means were compared using Least Significant Difference $(\mathrm{LSD})$ test $(\mathrm{P}<0.05)$. The model used for data analysis was;

$$
\begin{aligned}
& \text { Yij }=\mu+\mathrm{Ti}+\text { eij } \\
& \text { Where, } \\
& \text { Yij }=\text { is an observation (experimental unit) } \\
& \mu=\text { Overall means } \\
& \mathrm{Ti}=\text { Treatment effect } \\
& \text { eij = Random error term }
\end{aligned}
$$

\section{RESULTS AND DISCUSSION}

\section{Chemical composition of experimental diets}

The results of laboratory analysis for the different feed ingredients are shown in table 4. Among all ingredients, yeast contains the highest protein value and with respect to the total protein content, it seems to be good protein feed additive for poultry. Even though the total protein composition of a given feed is important, the quality of the essential amino acids and their composition determine to a considerable extent its nutritive value in poultry ration (Sukanya et al., 2017).

The rations $\mathrm{CP}$ and ME contents were almost in line with in the recommended levels of $22 \%$ and $20 \%$ and ME value of 3100 and $3200 \mathrm{kcal} / \mathrm{kg}$ for broilers during the starter and finisher phases, respectively on tables 1 and 2 (Leeson and Summers, 2005).

\section{Feed consumption}

The average daily feed intake of the four groups of chicks during the starter, finisher phases as well as the whole growth period are shown in table 5. Average daily and total intake of feed during the starter phase was not affected $(\mathrm{P}>0.05)$ by dietary treatment. But in finisher phase and entire experimental period average and total 
feed intake had significant difference $(\mathrm{P}<0.05)$. During finisher phase, total feed intake was higher for T1 than T3 and $\mathrm{T} 4$ but similar with $\mathrm{T} 2$ and average feed intake also high in $\mathrm{T} 1$ and $\mathrm{T} 2$ than $\mathrm{T} 3$ and $\mathrm{T} 4$. For the whole experimental period, total feed intake for all treatment groups was significantly different $(\mathrm{P}<0.05)$ and at the level of supplemental yeast increases, the birds consume less feed. In terms of total feed intake, the present results showed that chicks fed a diet containing $0 \%$ baker's yeast
(T1) consumed more quantity of feed than the yeast containing treatment groups. The present study is in agreement with those of Adebiyi et al. (2012) and Nihar et al. (2016), who reported the lowest fed intake in all chickens given probiotic and highest in the control group. In addition, Shoeib and Madian (2002) also described low feed intake in the chickens fed on probiotic as compared to the control group.

Table 4. Chemical composition of feed ingredients

\begin{tabular}{|c|c|c|c|c|c|c|c|c|}
\hline \multirow[b]{2}{*}{ Ingredients } & \multicolumn{8}{|c|}{ Chemical composition } \\
\hline & $\begin{array}{l}\text { DM } \\
(\%)\end{array}$ & $\begin{array}{c}\text { CP } \\
(\% \mathrm{DM})\end{array}$ & $\begin{array}{c}\text { EE } \\
(\% \mathrm{DM})\end{array}$ & $\begin{array}{c}\text { CF } \\
(\% \mathrm{DM})\end{array}$ & $\begin{array}{c}\text { ASH } \\
(\% \mathrm{DM})\end{array}$ & $\begin{array}{c}\text { ME } \\
\text { (kcal/kg DM) }\end{array}$ & $\begin{array}{c}\text { Ca } \\
(\% \mathrm{DM})\end{array}$ & $\begin{array}{c}\mathbf{P} \\
(\% \mathrm{DM})\end{array}$ \\
\hline WS & 90.02 & 15.36 & 3.3 & 12.34 & 4.60 & 2848.28 & 0.15 & 0.71 \\
\hline SBM & 94.22 & 38.84 & 2.7 & 7.42 & 5.45 & 3217.37 & 0.37 & 0.32 \\
\hline NSC & 90.89 & 30.76 & 7.2 & 15.74 & 10.55 & 2516.10 & 0.35 & 0.83 \\
\hline
\end{tabular}

$\mathrm{DM}=$ Dry Matter; $\mathrm{CP}=$ Crude Protien; $\mathrm{EE}=$ Ether Extract; $\mathrm{CF}=$ Crude Fiber; $\mathrm{P}=$ Phosphorus; $\mathrm{Ca}=\mathrm{Calcium}$; $\mathrm{ME}=$ Metabolizable Energy, WS= Wheat short; $\mathrm{SBM}=$ Soybean meal; $\mathrm{NSC}=$ Noug seed cake; $\mathrm{BY}=$ Baker's yeast.

Table 5. Feed and nutrient intake of broilers fed diets with different levels of supplemental baker's yeast during the starter phase (1-21 days), finisher phase (22-45 days) and the whole growth period (1-45 days)

\begin{tabular}{|c|c|c|c|c|c|c|}
\hline \multirow{2}{*}{ Parameters } & \multicolumn{4}{|c|}{ Treatments } & \multirow{2}{*}{ SEM } & \multirow{2}{*}{ SL } \\
\hline & T1 & $\mathbf{T 2}$ & T3 & T4 & & \\
\hline \multicolumn{7}{|l|}{ Starter phase } \\
\hline Feed intake (g/bird) & 978.55 & 962.22 & 960.47 & 947.35 & 9.85 & NS \\
\hline Feed intake (g/bird/day) & 46.6 & 45.82 & 45.73 & 45.11 & 0.47 & NS \\
\hline \multicolumn{7}{|l|}{ Finisher phase } \\
\hline Feed intake (g/bird) & $3377.09^{\mathrm{a}}$ & $3355.16^{\mathrm{ab}}$ & $3314.69^{\mathrm{bc}}$ & $3292.65^{\mathrm{c}}$ & 9.35 & $*$ \\
\hline Feed intake (g/bird/day) & $140.71^{\mathrm{a}}$ & $140.03^{\mathrm{a}}$ & $138.11^{b}$ & $137.19^{\mathrm{b}}$ & 0.36 & $*$ \\
\hline \multicolumn{7}{|l|}{ Whole period } \\
\hline Feed intake (g/bird) & $4355.64^{\mathrm{a}}$ & $4317.38^{\mathrm{b}}$ & $4275.16^{\mathrm{c}}$ & $4240^{\mathrm{d}}$ & 4.38 & $*$ \\
\hline Feed intake (g/bird/day) & $96.41^{\mathrm{a}}$ & $95.04^{\mathrm{ab}}$ & $95.9^{\mathrm{a}}$ & $94.22^{\mathrm{b}}$ & 0.35 & $*$ \\
\hline
\end{tabular}

${ }_{\text {abcd }}$ Means within a row with different superscript letters are significantly different $(\mathrm{P}<0.05)$; NS = non-significant; SEM = Standard error of the mean; SL = Significance level; FI= Feed Intake; T1 = diet containing $0 \%$ of baker's yeast; T2 = diet containing $0.5 \%$ of baker's yeast; T3 = diet containing 1.5 of baker's yeast; $\mathrm{T} 4=$ diet containing $2.5 \%$ of baker's yeast.

\section{Body weight gain}

The growth rate of the experimental chicks during the starter, finisher and the whole growth period are presented in table 6. In this experiment chicks fed 2.5\% baker's yeast (Saccharomyces cerevisiae) supplementation in ration were significantly $(\mathrm{P}<0.05)$ increase the body weight gaining compared with other groups. Meanwhile, chicks fed $2.5 \%$ baker's yeast has higher feed conversion efficiency compared with the other dietary treatments (control and $0.5 \%$ baker's yeast). No negative effects were exerting on the addition of at all inclusion levels on internal body organs as compared with control.
At the end of starter phase, final body weight of bird was greater for $\mathrm{T} 4$ as compared to $\mathrm{T} 1$ and $\mathrm{T} 2$ but, similar with T3 groups. Results showed that the final body weight of birds during finisher phase and at the end of whole experimental period had higher body weight for $\mathrm{T} 4$ than $\mathrm{T} 1$ but, similar to other yeast containing treatment groups. Average daily body weight gain during the starter phase and the whole experimental period was significantly affected by treatment $(\mathrm{P}<0.05)$. The obtained results confirmed the previous findings of several researchers (Zhang et al., 2005; Paryad and Mahmoudi, 2008) that 
yeast supplementation in broiler ration had a significant effect on body weight gain and feed conversion ratio.

Gudev et al. (2008) and Patane et al. (2017) also reported that Saccharomyces cerevisiae improved feed/gain ratio and body weight gain. The present study revealed that baker's yeast supplementation had a positive effect on the body weight of broiler chickens in T4 for the whole trail period. This may be explained as one of the critical roles of probiotic yeast in the metabolic function is promoting a healthy or pathogen free gastrointestinal tract environment for the proper functioning of endogenous enzymes to break down the energy nutrients of the experimental rations and the competition between probiotic microorganism and pathogenic microorganisms for energy and nutrients are reduced. Then energy and nutrients are efficiently absorbed in Gastrointestinal tract of broilers. This in turn may have improved body weight and feed conversion efficiency of the chicks fed yeast added rations as compared to the chicks fed control or non-yeast added diets.

Table 6. Body weight change of broilers fed diets with different levels of supplemental baker's yeast during the starter phase (1-21 days), finisher phase (22-45 days) and the whole growth period (1-45 days)

\begin{tabular}{|c|c|c|c|c|c|c|}
\hline \multirow{2}{*}{ Items } & \multicolumn{4}{|c|}{ Treatments } & \multirow{2}{*}{ SEM } & \multirow{2}{*}{ SL } \\
\hline & T1 & T2 & T3 & T4 & & \\
\hline \multicolumn{7}{|l|}{ Starter Phase } \\
\hline Initial wt (g/bird) & 43.28 & 42.76 & 42.58 & 42.37 & 0.71 & NS \\
\hline Final wt (g/bird) & $478.63^{\mathrm{b}}$ & $494.36^{\mathrm{b}}$ & $495.56^{\mathrm{ab}}$ & $527.67^{\mathrm{a}}$ & 7.1 & $*$ \\
\hline Total weight gain (g/bird) & $435.35^{\mathrm{b}}$ & $451.77^{b}$ & $452.46^{\mathrm{b}}$ & $485.3^{\mathrm{a}}$ & 7.02 & $*$ \\
\hline ADG (g/bird/day) & $20.73^{\mathrm{b}}$ & $21.51^{\mathrm{b}}$ & $21.54^{\mathrm{b}}$ & $23.11^{\mathrm{a}}$ & 0.33 & $*$ \\
\hline FCR ( $\mathrm{g}$ feed/g gain & $2.25^{\mathrm{a}}$ & $2.13^{\mathrm{ab}}$ & $2.12^{\mathrm{ab}}$ & $1.95^{\mathrm{b}}$ & 0.04 & $*$ \\
\hline \multicolumn{7}{|l|}{ Finisher Phase } \\
\hline Initial wt (g/bird) & $478.63^{b}$ & $494.36^{\mathrm{b}}$ & $495.56^{\mathrm{ab}}$ & $527.67^{\mathrm{a}}$ & 7.1 & $*$ \\
\hline Final wt (g/bird) & $1784.72^{\mathrm{b}}$ & $1802^{\mathrm{ab}}$ & $1849.09^{\mathrm{ab}}$ & $1863.85^{\mathrm{a}}$ & 16.68 & $*$ \\
\hline Total weight gain (g/bird) & 1306.09 & 1307.64 & 1353.53 & 1336.17 & 16.68 & NS \\
\hline ADG (g/bird/day) & 54.42 & 54.48 & 56.4 & 55.67 & 0.69 & NS \\
\hline FCR ( $\mathrm{g}$ feed/g gain & 2.59 & 2.57 & 2.45 & 2.46 & 0.03 & NS \\
\hline \multicolumn{7}{|l|}{ Whole Period } \\
\hline Initial wt (g/bird) & 43.28 & 42.76 & 42.58 & 42.37 & 0.71 & NS \\
\hline Final wt (g/bird) & $1784.72^{b}$ & $1802^{\mathrm{ab}}$ & $1849.09^{\mathrm{ab}}$ & $1863.85^{\mathrm{a}}$ & 16.68 & $*$ \\
\hline Total weight gain (g/bird) & $1741.44^{\mathrm{b}}$ & $1759.41^{\mathrm{ab}}$ & $1806^{\mathrm{ab}}$ & $1821.48^{\mathrm{a}}$ & 16.61 & $*$ \\
\hline ADG (g/bird/day) & $38.7^{\mathrm{b}}$ & $39.1^{\mathrm{ab}}$ & $40.13^{\mathrm{ab}}$ & $40.47^{\mathrm{a}}$ & 0.37 & $*$ \\
\hline FCR (g feed/g gain) & $2.5^{\mathrm{a}}$ & $2.45^{\mathrm{ab}}$ & $2.37^{\mathrm{bc}}$ & $2.33^{\mathrm{c}}$ & 0.02 & $*$ \\
\hline
\end{tabular}

$\overline{a b c}$ Means within a row with different superscript letters are significantly different $(\mathrm{P}<0.05)$; NS $=$ non-significant; $\mathrm{SEM}=$ standard error of the mean; $\mathrm{SL}=$ Significance level; $\mathrm{ADG}=$ Average daily body weight gain; $\mathrm{g}=$ gram; $\mathrm{T} 1=$ diet containing $0 \%$ of baker's yeast; $\mathrm{T} 2=$ diet containing $0.5 \%$ baker's yeast; $\mathrm{T} 3=$ diet containing $1.5 \%$ baker's yeast; $\mathrm{T} 4=$ diet containing $2.5 \%$ of baker's yeast; $\mathrm{wt}=$ weight.

\section{Feed conversion ratio}

Feed conversion ratio of broilers during the starter, finisher phases and entire growth period of the experiment are presented in Table 6. Results of the experiment indicated that there was significant difference $(\mathrm{P}<0.05)$ in feed conversion ratio in broilers fed the starter rations. During finisher phase feed conversion ratio showed insignificant difference $(\mathrm{P}>0.05)$ among treatments. Feed conversion ratio (FCR) expressed as feed to gain and during whole growth period feed conversion ratio was showed significant difference $(\mathrm{P}<0.05)$ and the value was being greater for $\mathrm{T} 1$ and $\mathrm{T} 2$ than $\mathrm{T} 3$ and $\mathrm{T} 4$. A significant improvement in FCR was recorded in the supplemental yeast containing treatment groups. Yeast acts by reducing the feed conversion ratio, resulting in an increase in daily life weight gain. Birds that have a low FCR are considered as efficient users of feed. So attributable to this FCR of birds in T4 (2.5\% baker's yeast) and T3 (1.5\% baker's yeast) were low and efficiently feed utilizers than other groups.

The result is in agreement with Leeson and Summers (2006) who written 2-4 feed conversion ratios for poultry. 
Zhang et al. (2005) had also reported significant improvement in feed/gain ratio. In addition, Bansal et al. (2011) and Hana et al. (2015) reported significant and better feed conversion efficiency on probiotic supplementation in the diet of commercial broiler chicks. In the present study, this improvement of feed conversion ratio in yeast supplemented groups might be due to the one beneficial effects of yeast in improvement of the intestinal lumen health and thereby increasing the absorption and utilization of the dietary nutrients.

\section{Carcass parameters}

Results of the present study indicated that the average slaughter weight was not significantly differ (P>0.05) among the treatment groups (Table 7). However, significant difference $(\mathrm{P}<0.05)$ was observed in dressed and eviscerated carcass weight and percentage. In breast meat percentage, drumstick-thigh, abdominal fat, thigh, wing and drumstick weight and percentage there was no significant difference $(\mathrm{P}>0.05)$ among treatments. But, there was significant difference in breast meat weight for T4 compared to other treatments. Breast meat often has a higher economic value than meat from other parts of the poultry carcass (Sasidhar, 2006 and Eltazi et al., 2014). The author also reported that the main concern of people producing broilers is unnecessary accumulation of carcass fat, particularly in the abdominal area, as this fat is not accepted by consumers it becomes a waste to the processor. Even if the statistical results showed insignificant difference in abdominal fat weight and percentage among treatments, it was a bit higher for the groups kept on the control group than T2, T3 and T4.

Table 7. Carcass yield characteristics of broilers fed different level of supplemental baker's yeast from 1-45 days of the period.

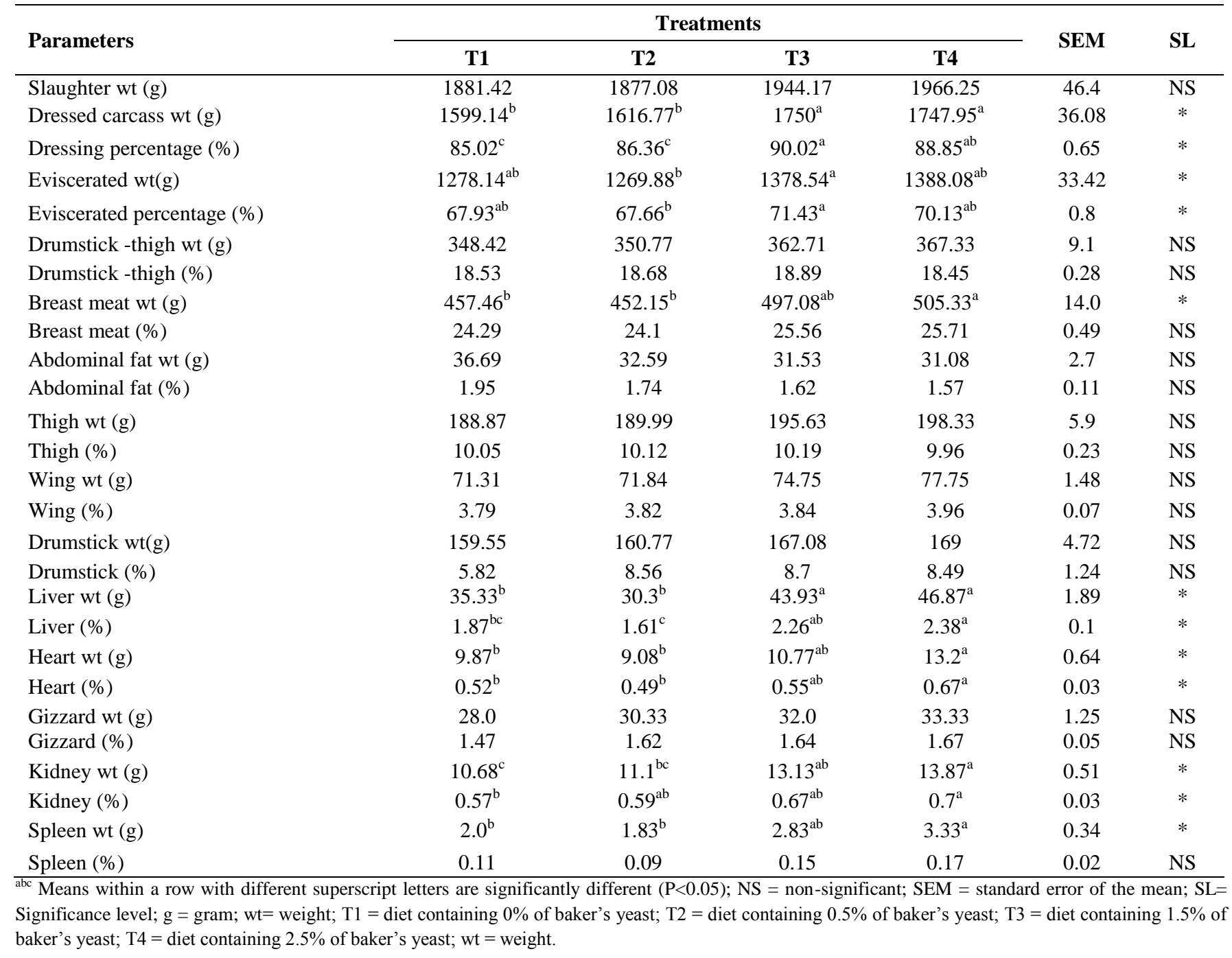


In study, Kalavathy et al. (2003) found that supplementation of $S$. cerevisiae reduces $(\mathrm{P}<0.05)$ abdominal fat pad. Similarly, Anjum et al. (2005) and Safalaoh (2006) also reported that supplementation of yeast had produced low level $(\mathrm{P}<0.05)$ of abdominal fat pad. This result is similar with several studies that reported lowering of abdominal fat by yeast supplementation than non-supplementation (control group), indicating the fact that baker' yeast enhance efficient energy usage.

Baker's yeast ( $S$. cerevisiae) affect significantly spleen weight, liver, heart and kidney weight and percentage, crop length, caeca and small intestine weight. The results agreed with that of Ivanov (2004); Penkov et al. (2004); Dimcho et al. (2005) and Onwurah and Okejim (2014) reported more improvements in liver, and heart of broilers, mules and ducklings by supplementing diets with probiotics. However, it is in contrast with the findings by
Hussein and Selim (2018) who reported that dietary probiotic supplementation did not increase the liver weights of broiler chickens. As indicated on Table 8 entire mass of the small intestine in T3 and T4 groups were heavier than the weights of intestine from other experimental groups. Gao et al. (2008) also noted that yeast culture inclusion at a level of $0.25 \%$ increased $(\mathrm{P}<0.05)$ small intestine weight in broilers. This result is in contrast with the findings by Alcicek et al. (2004), who reported that dietary supplementation of probiotics lowered the weight of the small intestine. Finally, nonsignificant differences were seen in spleen percentage, gizzard, crop, proventriculus weight and percentage and caeca and small intestine length. In addition, there was no significant effect of the probiotic on the weights of organs like crop and gizzard (Çınar et al., 2009).

Table 8. Non-edible offal components of broilers fed different level of supplemental baker's yeast from 1-45 days of the period.

\begin{tabular}{|c|c|c|c|c|c|c|}
\hline \multirow{2}{*}{ Parameters } & \multicolumn{4}{|c|}{ Treatments } & \multirow{2}{*}{ SEM } & \multirow{2}{*}{ SL } \\
\hline & T1 & T2 & T3 & T4 & & \\
\hline Crop weight (g) & 8.58 & 8.3 & 11.27 & 11.43 & 1.13 & $\mathrm{NS}$ \\
\hline Crop length $(\mathrm{cm})$ & $13.79^{\mathrm{b}}$ & $16.34^{\mathrm{a}}$ & $15.83^{\mathrm{ab}}$ & $15.79^{\mathrm{ab}}$ & 0.45 & $*$ \\
\hline Proventriculus weight (g) & 9.66 & 11.88 & 10.16 & 10.66 & 1.48 & NS \\
\hline Proventriculus length $(\mathrm{cm})$ & 9.87 & 12.15 & 9.14 & 7.58 & 1.21 & NS \\
\hline Caeca weight $(\mathrm{g})$ & $12.66^{\mathrm{b}}$ & $14.38^{\mathrm{ab}}$ & $18.75^{\mathrm{a}}$ & $19.5^{\mathrm{a}}$ & 1.3 & $*$ \\
\hline Small intestine weight (g) & $60.67^{\mathrm{c}}$ & $66.33^{\mathrm{bc}}$ & $101.75^{\mathrm{a}}$ & $85.75^{\mathrm{ab}}$ & 5.32 & $*$ \\
\hline Small intestine length $(\mathrm{cm})$ & 177 & 168 & 196.67 & 180.22 & 7.15 & NS \\
\hline
\end{tabular}

${ }^{\mathrm{abc}}$ Means within a row with different superscript letters are significantly different $(\mathrm{P}<0.05)$; NS = non-significant; $\mathrm{SEM}=\mathrm{Standard}$ error of the mean; SL $=$ Significance level; $\mathrm{cm}=$ centimeter; $\mathrm{g}=$ gram; $\mathrm{T} 1=$ diet containing $0 \%$ of baker's yeast; $\mathrm{T} 2=$ diet containing $0.5 \%$ of baker's yeast; T3 = diet containing 1.5 of baker's yeast; $\mathrm{T} 4=$ diet containing $2.5 \%$ of baker's yeast.

\section{Hematology evaluation}

The values obtained for all hematological parameters of broilers fed graded levels of baker's yeast in ration (Table 9) showed that $\mathrm{Hb}(10.96$ - $12.5 \mathrm{~g} / \mathrm{dl})$ and PCV (32.42 - 35.63\%) were within normal range of 6.0-13.0 $\mathrm{g} / \mathrm{dl}$ and $29-38 \%$ for $\mathrm{Hb}$ and PCV, respectively (Nworgu, 2007). Hematological constituents reflect the physiological state of the animals to its internal and external environment (Chowdhury et al., 2005). RBC was also within the range of $1.0-3.0\left(\times 10^{6} / \mathrm{mm}^{3}\right)$ and no reduction in total WBC were recorded in chicks of all treatment groups with or without yeast at its four graded levels within the normal range of $1.099 .06 \times 10^{3} / \mathrm{mm}^{3}$ reported by Douglas et al. (2010). These indices could have contributed to the better performance of the broilers at both phases. The use of baker's yeast had no significant effects on RBC for all treatment groups, but differences between treatments were significant for $\mathrm{Hb}$ and $\mathrm{PCV}(\mathrm{P}<$ 0.05). All yeast fed chicks in compare to control diet had more WBC. The yeast can stimulate immune system of chick's body so, it affects WBC. Mohamed et al. (2015) reported a positive correlation between dietary levels of S.cerevisiae with the haematological indices like, RBC, WBC and PCV in rabbit and broiler chickens. The results agreed with Shareef and Al-Dabbagh (2009) that reported there was no reduction in total white blood cells and hemoglobin with supplemental yeast fed to broilers.

Normal hematological values reveal the nutritional status of animal. Thus, the normal values observed in the present study indicate the adequacy of nutrients for the birds. Oladele et al. (2001) reported that linked lower values of these parameters to inadequate nutrition. It also 
implies that the immune systems of the chicks are adequate. Even though $\mathrm{Hb}, \mathrm{PCV}$ and $\mathrm{RBC}$ values are within the normal range, the higher values observed in broilers consumed ration containing yeast as compared to the control diet suggest that yeast improved nutrient utilization and assimilation in to the blood stream for use by the birds and enhanced blood formation due to availability of essential nutrients.

\section{Mortality}

Rate of mortality recorded from the experimental chicks are shown in table 9. During the trial period there was no observable sign of morbidity recorded but mortaliti es occurred fortuitously within the first 2 weeks of the study. May be due to stress and mechanical injury during transportation. Mortality percent of broilers during experimental period was $10.00,6.67,6.67$ and 3.33 $(\mathrm{SEM}=2.89)$ for $\mathrm{T} 1, \mathrm{~T} 2, \mathrm{~T} 3$ and $\mathrm{T} 4$, respectively and there was no significant difference $(\mathrm{P}>0.05)$ in mortality percentage among the treatments. But numerically the highest mortality rate was seen in $\mathrm{T} 1$ and the lowest mortality rate was observed in T4. All mortalities occurred during the first phase of feeding trail and it was not reported in all groups of this experiment during the second phase. This observation could be in accordance with that mention yeast is used to stimulate the animal's immune system, thereby further reducing the risk of disease (Laegreid and Bauer, 2004). Also several workers (Shashidhara and Devegourda, 2003; Goa et al., 2008) reported that (Saccharomyces cerevisiae) improved the efficiency of immune system of broilers. Similar findings were obtained by Świątkiewicz et al. (2014) who found positive effect of dietary (Saccharomyces cerevisiae) on mortality rate of broiler. In addition to Karaoglu and Durdag (2005) reported that, the use of probiotic (Saccharomyces cerevisiae) in the broiler diet reduced or prevented the mortality.

Table 9. Effect of graded levels of baker's yeast fed in ration of broiler on haematological indices and mortality rate during 1-45 days of age.

\begin{tabular}{|c|c|c|c|c|c|c|}
\hline \multirow{2}{*}{ Parameters } & \multicolumn{4}{|c|}{ Treatments } & \multirow{2}{*}{ SEM } & \multirow{2}{*}{ SL } \\
\hline & T1 & $\mathbf{T 2}$ & T3 & T4 & & \\
\hline Hemoglobin (g/dl) & $10.96^{\mathrm{b}}$ & $12.06^{\mathrm{ab}}$ & $12.17^{\mathrm{a}}$ & $12.5^{\mathrm{a}}$ & 0.24 & $*$ \\
\hline Packed cell volume (\%) & $32.42^{\mathrm{b}}$ & $34.63^{\mathrm{ab}}$ & $34.94^{\mathrm{ab}}$ & $35.63^{\mathrm{a}}$ & 0.7 & $*$ \\
\hline $\operatorname{RBC}\left(10^{6} / \mathrm{mm}^{3}\right)$ & 1.76 & 2.09 & 2.07 & 2.17 & 0.89 & NS \\
\hline WBC $\left(10^{4} / \mathrm{mm}^{3}\right)$ & $2.23^{\mathrm{b}}$ & $2.44^{\mathrm{a}}$ & $2.40^{\mathrm{ab}}$ & $2.46^{\mathrm{a}}$ & 0.56 & $*$ \\
\hline Mortality \% & 10 & 6.67 & 6.67 & 3.33 & 2.89 & NS \\
\hline
\end{tabular}

$\overline{\mathrm{abc}}$ Means within a row with different superscript letters are significantly different $(\mathrm{P}<0.05)$; NS = non-significant; $\mathrm{SEM}=\mathrm{Standard} \mathrm{Error} \mathrm{of} \mathrm{the} \mathrm{Mean;} \mathrm{SL}=$ Significance level; $\mathrm{RBC}=$ red blood cell; $\mathrm{WBC}=$ white blood cell; $\mathrm{g} / \mathrm{dl}=$ gram per deciliter; $\mathrm{T} 1=$ diet containing $0 \%$ of baker's yeast; $\mathrm{T} 2=$ diet containing $0.5 \%$ of baker's yeast; $\mathrm{T} 3=$ diet containing $1.5 \%$ of baker's yeast; $\mathrm{T} 4=$ diet containing $2.5 \%$ of baker's yeast.

Table 10. Partial budget analysis for broilers fed different levels of baker's yeast during 1-45 days of age.

\begin{tabular}{|c|c|c|c|c|}
\hline \multirow{2}{*}{ Variables } & \multicolumn{4}{|c|}{ Treatment } \\
\hline & T1 & T2 & T3 & T4 \\
\hline Purchase price/bird (birr) & 20 & 20 & 20 & 20 \\
\hline Price $/ \mathrm{kg}$ of carcass (supermarket) & 140 & 140 & 140 & 140 \\
\hline Feed cost/bird (birr) & 26.96 & 27.07 & 28.6 & 30.93 \\
\hline Other cost/bird (birr) & 1.15 & 1.15 & 1.15 & 1.15 \\
\hline NR (birr) & 130.83 & 129.56 & 143.25 & 142.25 \\
\hline$\Delta \mathrm{NR}$ & 0.00 & -1.27 & 13.69 & -1 \\
\hline$\Delta \mathrm{TVC}$ & 0.00 & 0.11 & 1.53 & 2.33 \\
\hline MRR & 0.00 & -11.54 & 8.95 & -0.43 \\
\hline Chicks sale/feed cost & 6.64 & 6.57 & 6.75 & 6.28 \\
\hline
\end{tabular}




\section{Partial budget analysis}

Differences in feed cost, chick sale and chick's sale to feed cost ratio were noticed among the treatment groups (Table 10). The highest net income and marginal rate of return were obtained for $\mathrm{T} 3$ ration followed by T4. Therefore, T3 appeared to be economical in economic parameters used in the study. The chicks' sale to feed cost ratio was estimated as additional parameter to see the importance of inclusion baker's yeast on ration of broilers during both starter and finisher phases. The birds in T3 score highest chicks' sale to feed cost than T1, T2 and T4. The lower ratio of chick's sale to feed cost was resulted from higher price of baker's yeast and low body weight gain. Therefore, the results of this study indicated that ration containing $1.5 \%$ addition of baker's yeast is potentially profitable than the other levels of inclusion in the ration under the condition of the present experiment.

\section{CONCLUSION}

In conclusion, baker's yeast can be an important feed additive, which can be included up to $2.5 \%$ of the total ration and improve the overall performance of broilers without compromising the hematological indices of broiler chickens. Generally, the present study can be a gate-way for further researches on how to use baker's yeast as an efficient protein feed additive in poultry ration.

\section{DECLARATIONS}

\section{Competing interests}

The authors declare that they have no conflict of interest.

\section{Author's contributions}

This manuscript is part of Kassech Mulatu MSc Thesis, where Negassi Ameha and Meseret Girma were advisors of her. Meseret Girma prepared of the manuscript. All authors read and approved the manuscript.

\section{REFERENCES}

Adebiyi OA, Makanjuola BA, Bankole TO and Adeyori AS (2012). Yeast Culture (Saccharomyces cerevisae) Supplementation: Effect on the Performance and Gut Morphology of Broiler Birds. Global Journal of Science Frontier Research Biological Sciences, 12(6): 25-29.

Alcicek A, Bozkurt M and Cabuk M (2004). The effects of a mixture of herbal essential oil, an organic acid or a probiotic on broiler performance. South African Journal of Animal Science, 34: 217-222.
Anjum ML, Khan AG, Azim A and Afzal M (2005). Effect of dietary supplementation of multi-strain probiotic on broiler growth performance. Pakistan Veterinary Journal, 25 (1): 25-29.

AOAC (Association of Official Analytical Chemists) (1995). Official Methods of Analysis of AOAC International (16th edition). Virginia. USA.

Apata DF (2009). Antibiotic Resistance in Poultry. International Journal of Poultry Science, 8 (4): 404-408. DOI: 10.3923/ijps.2009.404.408.

Bansal GR, Singh VP and Sachan N (2011). Effect of probiotic supplementation on the performance of broilers. Asian Journal of Animal Science, 5: 277-284. DOI:ajas.2011.277.284.

Chowdhury SR, Smith TK, Boermans HJ and Woodward B (2005). Effects of feed-borne fusarium mycotoxins on hematology and immunology of laying hens. Poultry Science, 84:1841-1850. DOI:https://doi.org/10.1093/ps/84.12.1841

Çınar M, Çatlı AU, Küçükyılmaz K and Bozkurt M (2009). The effect of single or combined dietary supplementation of prebiotics, organic acid and probiotics on performance and slaughter characteristics of broilers. South African Journal of Animal Science, 39: 197-205. DOI: http://dx.doi.org/10.4314/sajas.v39i3.49152.

Dacie JUand Lewis SM (1991). Practical Hematology. $8^{\text {th }}$ edition. Longman Ltd London. pp 22-48.

Dimcho D, Svetlana B, Tsvetomira S and Tatiana V (2005). Effect of feeding Lactina probiotic on performance, some blood parameters and caecal microflora of mule ducklings. Trakian Journal of Science, 3 (2): 22-28.

Douglas J, Weiss K and Wardrop J (2010). Veterinary Hemathology. 6th edition, Blackwell Publishing Ltd.

Eltazi SM, Mohamed KA and Mohamed MA (2014). Response of broiler chicks to diets containing live yeast as probiotic natural feed additive. International Journal of Pharmaceutical Research and Allied Sciences, 3(2): 40-46.

FAO (Food and Agriculture Organization of the United Nations) (2010). FAO Agbiz hand book of poultry meat. http:/www.responsibleagroinvestment.org.

Fietto JL, Araujo RS, Valadao FN, Fietto LG, Brandao RL, Neves MJ, Gomes FC, Nicoli JR and Castro IM (2004). Molecular and physiological comparisons between Saccharomy cescerevisiae and Saccharomyces boulardii. Canadian Journal of Microbiology, 50: 615-621. DOI: https://doi.org/10.1139/w04-050.

Fuller R (2000). The Chicken Gut Microflora and Probiotic Supplements. Journal of Poultry Science, 38: 189-196. DOI: $10.2141 /$ jpsa.38.189.

Goa J, Zhang HJ, Yu SH, Yoon I, Quigley J, Gao YP and Qi GH (2008). Effect of yeast culture in boiler diets on performance and immune-modulatory functions. Poultry Science, 87: 1377-1384. DOI: 10.3382/ps.2007-00418.

Graff S, Hussein S, Chaumeil JC and Charrueau C (2008). Increased intestinal delivery of viable Saccharomyces boulardii by encapsulation in microspheres. Pharmaceutical Research, 25 (6): 1290-1296. DOI: 10.1007/s11095-007-9528-5 
Gudev D, Popova-Ralcheval S, Moneva1 P and Ignatova M (2008). Effect of the probiotic "Lactona" on some biological parameters and nonspecific resistance in neonatal pigs. Biotechnology in Animal Husbandry, 24 (12): $87-96$.

Hana SE, Tyfor T, Iman MH, El Nasri M and Mukhtar AM (2015). Study of different levels of yeast on performance values and immune response in broiler chicken. Research Journal of Animal and Veterinary Sciences, 8(1): 1-5.

Hussein E and Selim S (2018). Efficacy of yeast and multi-strain probiotic alone or in combination on growth performance, carcass traits, blood biochemical constituents, and meat quality of broiler chickens. Livestock Science, 216:153159. DOI: https://doi.org/10.1016/j.livsci.2018.08.008.

Ivanov I (2004). Testing a probiotic mixture for broiler chickens. International Poultry science, 43: 44-47.

Kalavathy R, Abdullah N, Jalaludin S and Ho YW (2003). Effect of Lactobacillus cultures on growth performance, abdominal fat deposition, serum lipids and weight of organs of brother chickens. Brazilian journal Poultry Science, 44: 139-144.

Kanwal R, Abdur R and Mubarik M (2018). Effect of dietary supplementation of different levels of saccharomyces cerevisiae on growth performance and hematology in broiler. Indian Journal Animal Research, 52 (1): 1-6. DOI: 10.18805/ijar. B-695.

Karaoglu M and Durdag H (2005). The influence of dietary probiotic (saccharomyces cerevisiae) supplementation and slaughter age on the performance, slaughter and carcass properties of broilers. International Journal of Poultry Science, 4(3): 309-316. DOI: 10.3923/ijps.2005.309.316.

Kemal CK, Denl M and Ozturkcan O (2001). The effects of Saccharomyces cerevisiae and flavomycin on broiler growth performance. Pakistan Journal of Biology Science, 4: 1415-1417. DOI=pjbs.2001.1415.1417.

Laegreid WW and Bauer N (2004). Probiotics for pathogen control in poultry and livestock. American Meat Science Association Conference Reciprocal Proceedings. pp. 6974.

Leeson S and Summers JD (2005). Commercial Poultry Nutrition. 3rd Edition, Nottingham University Press, Canada, pp: 398.

Mohamed EA, Talha EA, Mojahid AA and Dafaalla EM (2015). Effect of dietary yeast (Saccharomyces cerevisiae) supplementation on performance, carcass characteristics and some metabolic responses of broilers. Animal and Veterinary Sciences, 3(5): 5-10. DOI: 10.11648/j.avs.s.2015030501.12.

Nihar RS, Babu LK, Kumar A, Pradhan CR, Pati PK and Mishra JP (2016). Effect of dietary supplementation of prebiotic, probiotic, and synbiotic on growth performance and carcass characteristics of broiler chickens. Veterinary World, 9(3): 313-319. DOI: 10.14202/vetworld.2016.313319.

Nworgu D (2007). Performance and some blood chemistry indices of broiler chicken served fluted pumpkin (Telferia occidentalis) leaves extract supplement. Journal of American-Eurasian Agricultural and Environmental Science, 2(1): 90-98.
Oladele SB, Ayo JO, Esievo KAN and Ogundipe SO (2001). Sea sonal and sex variations in packed cell volume, haemoglobin total protein of indigenous duck in Zaria Nigeria. Journal of Tropical Bioscience, 1(1): 84-88.

Onwurah FB and Okejim JC (2014). Effect of graded levels of baker's yeast (Saccharomyces Cerevisiae) in water on carcass and organ characteristics of broiler chickens. Academic Research International, 5(5): 128-133.

Patane AS, Premavalli K, Omprakash AV, John Kirubakaran J and Hudson GH (2017). Effect of dietary yeast supplementation on the production performance of broilers. International Journal of Advanced Biological Research, 7 (2): 222-228.

Penkov D, Gerzilov V, Nikolova B and Genchev D (2004). Study on the effect of probiotics Lactina feeding in bio farming of Muscovy ducklings. Growth performance. Animal Science, 4: 24-27.

Rolfe RD (2000). The role of probiotic cultures in the control of gastro-intestinal health. Journal of Nutrition, 130 (2): 396-402. DOI: 10.1093/jn/130.2.396S.

Safalaoh A (2006). Body weight gain, dressing percentage, abdominal fat and serum cholesterol of broilers supplemented with a microbial preparation. African Journal of Food Agriculture and Nutrition Development, 6: 1-10. DOI: 10.4314/ajfand.v6i1.19170.

Saied JM, Al-Jabary QH and Thalij KM (2011). Effect of dietary supplement yeast culture on production performance and hematological parameters in broiler chicks. International Journal of Poultry Science, 10: 376-380. DOI: 10.3923/ijps.2011.376.380.

Samuel Sahle (2008). The epidemiology and management options of chocolate spot disease (Botrytis fabae sard) on Faba bean (Vicia faba L.) in Northern Ethiopia. PhD Dissertation, Haramaya University, Ethiopia. 175p.

SAS (Statistical Analysis Systems) (2008). SAS/STAT user's guide, release 9.2. SAS Institute Inc. Cary, NC, USA.

Sasidhar PVK (2006). Assessment of Priority Research Areas in Poultry Sector to 2020. pp 1-11. Proceedings of National Seminar on poultry Research Priorities to 2020, 2-3 Novemeber, 2006. Central Avian Research Institute, Izatnagar, India.

Shareef AM and Al-Dabbagh ASA (2009). Effect of probiotic (Saccharomyces cerevisiae) on performance of broiler chicks. Iraqi Journal of Veterinary Sciences, 23(1): 23-29.

Shashidhara RG and Devegowda G (2003). Effect of dietary mannan oligosaccharide on broiler breeder production traits and immunity. Poultry Science, 82: 1319-1325. DOI:https://doi.org/10.1093/ps/82.8.1319.

Shoeib HK and Madian AH (2002). A study on the effect of feeding diets containing probiotics (Pronifer and biogen) on growth performance, intestinal flora and haematological picture of broiler. Journal of Veterinary Medicine, 47: 112125.

Sukanya K, Hajime K, Smerjai B, Ramphrai N and Patima B (2017). Effects of graded levels of liquid brewer's yeast on chemical composition and fermentation quality in cassava pulp and rice straw-based total mixed ration silage. Animal Science Journal, 88: 618-624. DOI: 10.1111/asj.12682. 
Świątkiewicz S, Arczewska-Włosek A and Józefiak D (2014). Immunomodulatory efficacy of yeast cell products in poultry: a current review. World's Poultry Science Journal, 70(1): 57-68. DOI: 10.1017/S0043933914000051.

Toms C and Powrie F (2001). Control of intestinal inflammation by regulatory T cells. Microbes Infection, 3: 929-935.

Upton M (1979). Farm Management in Africa, the Principal of Production and Planning, Oxford University Press, p. 380.

Wiseman J (1987). Feeding of non-ruminant animals. In Meeting nutritional requirement from available resources. Butter worth and Co. Ltd. London. pp. 9-15.

Zhang AW, Lee BD, Lee SK, Lee KW, An GH, Song KB and Lee CH (2005). Effect of yeast (Saccharomyces Cerevisiae) cell components on growth performance, meat quality and ileal mucosa development of broiler chicks.
Poultry
Science,
84 :
1015-1021.

DOI:https://doi.org/10.1093/ps/84.7.1015. 